\title{
Law Effect of Leave Notary in Implementation Position Based on the Act No. 2 of 2014 On Notary
}

\author{
Rizqi Agung Pratiwi ${ }^{1}$, Siti Juwariyah ${ }^{2}$ and Munsharif Abdul Chalim ${ }^{3}$
}

Abstract. Notary is competent public authority or his duty is to make the deeds authentic. Notaries have the right to take leave in accordance with Law Notary. Leave notaries are leaving the work of notaries in some time officially to rest, take a vacation or to become public officials. The purpose of this study to analyze how the legal consequences leave notary on the implementation of office in accordance with Act No. 2 of 2014 concerning Notary, the legal position of notaries replacement which replaces the notary in the period of leave, challenges and solutions faced by a substitute notary in implementing the office notary supplants the leave period. Legal Theory used in this research is the theory of Responsibility and Theory of Rule of Law.

The effects of this study indicate that there are no legal consequences for the notary who take leave, when he took a leave of absence he has appointed a substitute notary, if in the future in which no party feels aggrieved as a effect of his actions then Substitute Notary to be held responsible, even though they had quit his respective duties as Notary Public; Substitute notary legal position that replaces the notary in the period of leave is a substitute notary has authority as a notary as by UUJN; Challenges and solutions faced by a substitute notary in implementing the replaced notary office within the period of leave such as a lack of knowledge or ignorance, inexperience and lack of understanding. The solution is to appoint a substitute notary notaries, notary substitute must have the precautionary principle, accuracy and precision in implementing the notary office of his predecessor in the leave to avoid the occurrence of negligence in carrying out his post.

Keywords: Effects; Leave Notary; Notary Substitute.

\section{Introduction}

In Act No. 2 of 2014 amendments to the Act No. 30 Of 2004 on Notary (UUJN) stated that the notary is a public official who is authorized to make an authentic deed and have more authority as referred to in this law or by enactment other laws. ${ }^{4}$ Communities in their activities are mostly related to the law and in need of legal services is a Notary Public.

According to Act No. 2 of 2014 regarding the amendment of Act No. 30 of 2004 concerning Notary, notaries can be divided into three types, namely:

- Notary Public;

- Temporary officials; and

- Substitute Notary.

Notary is a public official has a duty and a great responsibility in carrying out his post to work professionally in society regardless of any angle, therefore, the duty of a

\footnotetext{
${ }^{1}$ Students of Master of Notarial Law, Faculty Of Law, Universitas Islam Sultan Agung email and Bawaslu staff of Cirebon, email: rapratiwi03@gmail.com

2 Students of Master of Law, Faculty Of Law, Universitas Islam Sultan Agung email alaricmama17@gmail.com

${ }^{3}$ Faculty Of Law, Universitas Islam Sultan Agung

${ }^{4}$ Article 1 paragraph 1 of Act No. 2 of 2014 on the amendment of Act No. 30 of 2004 concerning Notary
} 
notary in serving the community is not limited by time and must be able to work at any time as long as people need legal services, Acting Notary is someone who temporarily served as Notary to execute a notary office of the deceased. Substitute notary is someone who is temporarily appointed as a notary to replace the notary who is on leave, sick or temporarily unable to carry out his position as a notary. ${ }^{5}$

Notary leave may be granted if a Notary has conducted his post for two years and if it is less than 2 years, the Notary can not take the leave rights. Leave requests submitted to the MPD in the period of leave not more than six (6) months, MPW within the period of leave not more than six (6) months to one (1) year, or MPP within the period of leave more than 1 (one) years. ${ }^{6}$ Leave requests received by the MPD, MPW or MPP at the latest within a period of 30 (thirty) days before the leave carried out, unless there are other legitimate reasons. Notary leave requests to the authorities to attach supporting documents such as:

- Photocopy of the appointment or removal decision notary who has been delegated;

- Photocopy of the minutes of the oath / pledge notary office that has been in the delegation;

- Substitute notary appointment letter; and

- Leave the original certificate notary.

The appointment of a substitute notary must meet the following requirements:

- Indonesian citizens;

- Bachelor degree in law; and

- Has worked as an employee for a minimum Notary Office 24 (twenty four) consecutive months;

- Minimum age of 27 (twenty seven) years.

The appointment of a substitute notary must attach supporting documents, as follows:

- Photocopying law graduate diploma legalized;

- Photocopy of identity card legalized;

- The original certificate of local police records;

- Genuine spiritual health certificate from the psychiatric hospitals;

- Color photograph 3x4 cm size four (4) pieces;

- Curriculum Vitae; and

- The certificate has been working as an employee of the Notary office minimum of 24 (twenty four) consecutive months. ${ }^{8}$

Leave a notary who was appointed state officials are required to take leave to file a written request to MPP by attaching:

- Photocopying or displacement Notary Appointment Decisions that have been validated;

- Decision photocopy appointment as State officials that have been validated;

- Photocopy of the minutes of the oath / pledge Notary office that has been validated;

- Photocopy of the minutes of the oath / pledge as State officials that have been validated; and

- Leave the original certificate notary.

\footnotetext{
${ }^{5}$ Salim HS, 2018, Peraturan Jabatan Notaris, Sinar Grafika, Jakarta, p. 22.

${ }^{66}$ Article 27 paragraph 2 of Act No. 30 of 2004; Article 16, paragraph 1 Permenkumham No. 25 of 2014

${ }^{7}$ Article 16 paragraph (2), Ibid.

${ }^{8}$ Freddy Harris, Leny Helena, 2017, Notaris Indonesia, Jakarta, Pt Lintas Cetak Djaja, p.159.
} 
Leave valid for Notary taking office as State officials. Leave requests must be received by MPP within a period of 30 (thirty) days from the date of decree as state officials set. $^{9}$

Substitute notary is obliged to hand back to the notary protocol after the leave ends. ${ }^{10}$ Handover made the official report and submitted to the Supervisory Council of the Territory. ${ }^{11}$ Execution of duties by Acting Notary office Notary, the Notary Substitute limited by the time specified in the decree of appointment. When the time is finished, then Acting Notary shall hand back office and protocol to the Notary appointed by the Board of Supervisors Notary and Notary Substitute obligated to deliver back office and protocol to the notary replaces, while the Substitute Notary Special just for the deed particular in accordance with the specified in the decision. Thus Acting Notary, the Notary Substitutes and Special Substitute Notary in carrying out his duties temporary. Based on the descriptions above, the authors are interested in doing research by lifting the title " Law Effect of Leave Notary In Implementation Position Based on the Act No. 2 of 2014 On Notary ".

\section{Research methods}

Method the approach used in this study is empirical juridical approach. Juridical empirical approach in this study is that in analyzing the problems is done by combining secondary data with primary data collected in the field. Sources of data in this study with the primary data is conducted interviews to speakers, namely Notary Cirebon regency, West Java. Secondary data by documentation obtained from the field.

\section{Results and Discussion}

\subsection{The legal consequences of the implementation of furlough notary office in accordance with Act No. 2 of 2014 concerning Notary}

Notary leave may be granted if a Notary has conducted his post for two years and if it is less than 2 years, the Notary can not take the leave rights. When carrying out the leave, Notary concerned shall appoint a Substitute Notary to run the office. ${ }^{12}$ There are four requirements Substitute Notary appointed by the notary who leave include:

- Indonesian citizens;

- Bachelor degree in law;

- Has worked as an employee of a notary's office for a minimum of 24 (twenty four) consecutive months; and

- Be at least 27 years. ${ }^{13}$

Notary authorized limits, Acting Notary, the Notary Substitutes and Special Substitute Notary different. Acting on authority limits Substitute Notary and ends when the limit specified in the decision have been exhausted, and the Special Substitute Notary deed

\footnotetext{
${ }^{9}$ Ibid.

${ }^{10}$ Article 32 paragraph (2) of Act No. 2 of 2014 concerning Notary.

${ }^{11}$ Article 32 paragraph (3), Ibid, p. 21.

12 https://notariscimahi.co.id/notaris/hak-cuti-notaris, Accessed October 28, 2018, 23:05 pm pkl.
}

${ }^{13}$ Article 22 paragraph 3 of the Regulation of the Minister of Law and Human Rights No. 25 of 2014 on Conditions and Procedure for Appointment, Transfer, Termination and Extension of Term of Office Notary. 
shall end when he made the appropriate decree was completed. Notaries who take leave no legal consequences on the implementation of his position, because he has appointed a notary substitute to take his place while he was leave. The limit of accountability notary, Acting Notary, the Notary Substitutes and Special Substitute Notary may be requested as long as they are competent in carrying out duties as a notary office or error committed in performing their duties as Notary office may apply sanctions against a Notary, during Notary, Acting Notary, the Notary Substitutes and Special Substitute Notary is authorized to perform the duties of office as Notary. When referring to the theory of legal responsibility that there is an error, in which no party feels aggrieved as a effect of his actions then Substitute Notary to be held responsible, even though they had quit his duties as Notary.

\subsection{Legal position that replaces the substitute notary notarized the leave period}

Have the same legal status with a notary who is replaced by UUJN Article 33, paragraph 2. Notary substitute filed with the appointment procedure set forth in Article 27 UUJN sworn by an authorized officer, notary replacement should be accountable when mistakes or omissions in deed adverse parties. Notary substitute in the implementation of his position must always be based on Act No. 2 of 2014 on amendment of Act No. 30 of 2004 concerning Notary and Notary Code.

Requirements to be appointed as a substitute notary is defined in Article 33 UUJN as follows:

- Requirements to be appointed as a substitute notary, notary specific replacement, and acting notary is an Indonesian citizen who qualified Bachelor of Law and has worked as an employee of a notary's office at least two (2) consecutive years.

- Provisions applicable to notaries as referred to in Article 15, Article 16 and Article 17 apply to substitute notaries, notary specific replacement, and acting notary, unless the law otherwise provides.

Under the provisions of Article 1 point 3 UUJN conjunction with Article 33 paragraph (2) UUJN is intended to regulate the legal status (rechtpositie) From the substitute notary as a notary. With such a legal position means a substitute notary is a public officer as defined in Article 1868 of the Civil Code. ${ }^{14}$ So it can be said that a substitute notary has authority as a notary as by UUJN, ie, as a public officer appointed for a while and have the authority as a notary public. Substitute notary appointed by the competent authority based UUJN, not by the notary who proposed it or pointing to it. Assertions about the legal position of a substitute notary is necessary not only for the sake of a substitute notary, but especially for public interest uses substitute notary services. With the equality law among notary substitute with a notary then no doubts anymore that the deed made by the notary substitute has the same legal force to the deed of the notary, which means that the deeds made by or before a notary substitute character authentic and have the perfect strength of evidence as referred to in Article 1870 of the Civil Code.

\subsection{Challenges and solutions faced by a substitute notary in implementing the replaced notary office within the period of leave}

${ }^{14}$ Code of Civil law. 
Volume 6 Issue 2, June 2019

The obstacles are a lack of knowledge or ignorance (onvoldoende kennis); inexperience or flying hours (onvoldoende ervaring); and a lack of understanding (onvoldoende Inzicht). The solution that is a substitute notary shall have the precautionary principle, accuracy and precision in implementing the notary office of his predecessor in the period of leave. The precautionary principle is the application of Article 16 paragraph 1 letter a, which states "in running the notary office shall act carefully". Interest enactment of the precautionary principle is nothing for notary always in the correct signs. With the enactment of the precautionary principle it is expected that public confidence in the notary remains high, so that people are willing and have no hesitation in using the services of a notary.

\section{CLOSING}

\section{Conclution}

Based on the effects of research and discussion raised in this paper, it can be concluded:

- The legal consequences leave a notary public on the implementation of position based on Act No. 2 of 2014 concerning Notary, Limit of Liability Notary, Acting Notary, the Notary Substitute and the Substitute Notary Special can be requested as long as they are competent in carrying out duties of office as Notary or errors made in the running Notary office duties as may be imposed sanctions against a Notary, during Notary, Acting Notary, the Notary Substitutes and Special Substitute Notary is authorized to perform the duties of office as Notary. When referring to the theory of legal responsibility that there is an error, in which no party feels aggrieved as a effect of his actions then Substitute Notary to be held responsible, even though they had quit his duties as Notary.

- With the equality law among notary substitute with a notary then no doubts anymore that the deed made by the notary substitute has the same legal force to the deed of the notary, which means that the deeds made by or before a notary substitute character authentic and have the perfect strength of evidence as referred to in Article 1870 of the Civil Code.

- The obstacles are a lack of knowledge or ignorance (onvoldoende kennis); inexperience or flying hours (onvoldoende ervaring); and a lack of understanding (onvoldoende Inzicht). The solution that is a substitute notary shall have the precautionary principle, accuracy and precision in implementing the notary office of his predecessor in the leave to avoid the occurrence of negligence in carrying out his post.

\section{Bibliography}

[1] Act No. 30 of 2004 on concerning Notary.

[2] Act No. 2 of 2014 on the amendment of Act No. 30 of 2004 Notary.

[3] Code of Civil law.

[4] Regulation of the Minister of Law and Human Rights No. 25 of 2014 on Conditions and Procedure for Appointment, Transfer, Termination and Extension of Term of Office Notary.

[5] Freddy Harris, 2017, Leny Helena, Notaris Indonesia, Jakarta, Pt Lintas Cetak Djaja 
[6] R. Soegondo Notodisoerjo, 1982, Hukum Notariat di Indonesia Suatu Penjelasan, Jakarta, Rajawali

[7] Salim HS, 2018, Peraturan Jabatan Notaris, Sinar Grafika, Jakarta.

[8] https://notariscimahi.co.id/notaris/hak-cuti-notaris, Accessed October 28, 2018, 23:05 pm pkl. 